\title{
Who Reads Shashi? 'The Case of the Hiroshima Regional Newspaper
}

\author{
Ann Sherif \\ Oberlin College
}

\begin{abstract}
The company history of a newspaper company raises new questions about the genre of company histories. Who reads them? What features should readers and researchers be aware of when using them as a source? This article examines the shashi of the Chügoku Shinbun, the Hiroshima regional newspaper. The atomic bombings of Hiroshima and Nagasaki in August 1945 were significant because of their perceived role in bringing World War II to an end and in signaling the start of the nuclear age. Most research to date has emphasized the role of national newspapers and the international media in informing the public about the extent of the damage and generating a framework within which to understand. I compare the representation of three key events in the Chügoku Shinbun company history (shashi) to those in two national newspapers (Asahi and Yomiuri), as well as the ways that the Hiroshima company's $100^{\text {th }}$ and $120^{\text {th }}$ year self-presentations reveal important concerns of the region and the nation, and motivations in going public with its shashi. These comparisons will reveal some of the merits and limits of using shashi in research. This article is part of a larger study on the work of the influence of regional press and publishers on literature in twentieth-century Japan.
\end{abstract}

$\mathrm{T}$ The Chügoku Shinbunsha is the major newspaper and publishing company of the Chūgoku region (Hiroshima, Yamaguchi, Okayama, and Shimane Prefectures) of western Honshu. ${ }^{1}$ In this article, I examine the newspaper's company history (shashi), and, in particular, discuss the type of image the Chügoku Shinbun shashi writers constructed in their historical narrative, with the goal of promoting awareness of potential biases in the shashi and evaluating its usefulness as a source for researchers. A newspaper's approach to writing a shashi is heavily influenced by the conception of its numerous roles as a powerful institution in society and, since the late twentieth century, by the challenge to that authority resulting from historical and technological change propelling the development of competing media such as television and the Internet. This study of Chūgoku Shinbun and publishing in Hiroshima is part of an ongoing larger project about independent and regional publishers and presses, and the ways they shaped literature in twentieth-century Japan.

In this article, I compare the company history of the Chügoku Shinbun, a regional block newspaper (burokkushi) with those of two national newspapers (zenkokushi), Asahi Shinbun and Yomiuri Shinbun. ${ }^{2}$ The

\footnotetext{
${ }^{1}$ The Chūgoku Shinbunsha, as of this writing, is a conglomerate of 18 companies that include the newspapers, printing, digital, cultural activities, a local television station, sales, cable television, the non-profit Hiroshima International Cultural Foundation, among others. http://www.chugoku-np.co.jp/prf/kanren/index.html

${ }^{2}$ Newspapers in Japan are divided into three major categories: national newspapers, block newspapers, and regional newspapers (chihōshi). The block newspapers were originally formed by "forced amalgamation" during WWII. Susan Pharr and Ellis Krauss, eds, Media and Politics in Japan (Honolulu: University of Hawaii Press, 1996), 37.
} 
analysis considers the categories of narrative genre, visual image, and historiography, as they contribute to the shashi's construction of a company's identity. Although all shashi aim at guiding reception by readers through narrative and visual means, a newspaper company is particularly adept at shaping readers' opinions and world views. In addition, this article considers intended readerships and the ways choice of readership influences the focuses and generic approaches of a shashi, and those of related products with a broader circulation. In most cases, the company producing the shashi carefully controls its distribution, primarily targeting employees, libraries, and companies in the same business. ${ }^{3}$ The question of intended readership is important to researchers who use shashi because an author's narrative approach is heavily shaped by the assumptions about the horizon of expectations of readers and the type of image the company intends to project on that audience.

Newspaper companies depend on the shashi as a source of content for other types of publications and products directed at general audiences. The primary objects of this study, the Chūgoku Shinbun Company and its shashi, for example, have received considerable attention since the 3-11 Fukushima nuclear disaster, as researchers and citizens explore the links between Hiroshima and Fukushima, and between military uses of nuclear power and peaceful uses. ${ }^{4}$ For this reason, the newspaper company decided to target a general audience by producing a television series (DVD) and booklet based on its shashi's narrative of the atomic bombing (released in 2012). Examination of a newspaper company's publications and programs can thus reveal the initiatives of newspapers at a time when the viability of the newspaper as a medium is under question.

The Chūgoku Shinbun Company is a business interested in staying in business, and, as with other regional newspapers, in maintaining an influential presence in the local community. Since the early post-World War II era, the Chügoku Shinbun has emphasized coverage of atomic bomb history, peace education, and Hiroshima's identity as a "City of Peace." This identity has contributed substantially to Hiroshima's stature domestically and globally and to its economic development, as demonstrated by the continued maintenance of the Peace Park and related facilities and organizations, promotion of atomic bomb/peace tourism and school field trips, and successful application for UNESCO World Heritage for the Genbaku Dome. In this way, the newspaper's focus on Hiroshima's atomic bomb past and present, hibakusha (nuclear bomb survivors), and antinuclear ideals may be one of the oldest examples of what Anthony Rausch calls "revitalization journalism," a type of public activist journalism.

As Susan Pharr points out, it is essential to pay attention to the processes "by which the media relate to their audiences and the functions they perform for them" because the media have an important role in "creating communitas in contemporary democracies"-in other words, newspapers and other media "create a sense of bondedness within the community, as members of society join together to create a collective social reality."6 Although the work of newspaper and other media is to "channel ideas and information (both to and from elites, to and from society)," they are not neutral conduits. Rather, as Laurie Freeman notes, newspapers provide individual

${ }^{3}$ Only a handful of companies sell their shashi to the general public.

${ }^{4}$ An example of recent scholarly books that use the Chūgoku Shinbun shashi as a source is Fukuma Yoshiaki, Yamaguchi Makoto, and Yoshimura Kazuma, eds. Fukusü no "Hiroshima": kioku no sengo shi to media no rikigaku (Tokyo: Seikyusha, 2012). Other scholars look to the newspaper itself: Okuda Hiroko, Genbaku no kioku: Hiroshima Nagasaki no shisō (Tokyo: Keio Gijuku Daigaku Shuppankai, 2010). On the Chügoku Shinbun's coverage of the atomic bombings, see NHK Shuppan, ed. Hiroshima wa doo kiroku sareta ka: NHK to Chügoku Shinbun no genbaku hōdō (Tokyo: NHK Shuppan, 2003). The Japan Communist Party published a book that uses local company histories, including that of the Chügoku Shinbun, as a basis of chapters about the atomic bombing: Shinbun Akahata Chūgoku Shikoku sōkyoku, ed. Shashi ga kataru genbaku Hiroshima (Tokyo: Shin Nihon Shuppansha, 2003).

${ }^{5}$ Rausch, Japan's Local Newspapers: Chihōshi and Revitalization Journalism, (New York: Routledge, 2012). "The fate of the newspaper is ultimately tied up to fate of its local economy," he notes and defines revitalization journalism as a "specific form of journalism" that "incorporates both reporting 'on issues that are viewed as problems and creating solutions to these problems' and 'activating a local consciousness and activism about important themes,' all on a highly local level." Rausch describes this working in the Aomori paper he studies as the "journalistic activism" and calls it "revitalization journalism" because "local revitalization" is one of the "major themes" for the prefecture. (pp. 115-131). The majority of English-language studies of the Japanese press focus on the national newspapers and their connection with broadcast media and politics. See Ofer Feldman, Politics and the News Media in Japan (Ann Arbor: University of Michigan Press, 1993).

6 Pharr, "Media as Trickster," 37-38. Pharr's claim of course resonates with that of Benedict Anderson about the role of newspapers in forging "imagined communities." 
readers with "an ongoing framework for interpreting that information and for defining our social world." That work, in turn, "influences the setting and framing of social agendas" and legitimizes certain ideas and groups, while excluding others. ${ }^{7}$

\section{The Business of Newspaper Companies Locally and Nationally}

The press and scholars have long debated the roles of newspapers in society. Three general roles are posited. First, newspapers are businesses that function as impartial observers of society and conveyers of information. In his analysis of the public sphere, Habermas examines the early role of newspapers as businesses that primarily conveyed the day's news, without expressing an explicit point of view. ${ }^{8}$ Second, newspapers are advocates for the public good, watchdogs of society. From the eighteenth century, freedom of speech and the press guaranteed in constitutional democracies provided a basis for newspapers to adopt an editorial function, expressing and shaping public opinion and promoting public debate. Third, newspapers are servants of the state, or, since the twentieth century, agents of manipulation and control by the state and industry (powerful and wealthy non-state actors, such as corporations). This role surfaces in totalitarian societies, for example.

In democratic societies, newspapers view themselves as promoting key values of freedom of expression and freedom of the press, and work to ensure the reading public's right to know. In Japan, some postwar journalists describe the goal of investigative journalism as guided by the "principle of neutrality" (futo fuhen, separate from political party influence and bias), claiming a distinctly Japanese ethic that was influenced by European and American values of a free press, but evolved since Meiji in the particular historical circumstances of that country's press. $^{9}$

Scholars of newspapers and investigative journalism concur that newspapers often serve multiple roles, and that these roles change over time in relation to sociopolitical contexts. ${ }^{10}$ In late twentieth- and twenty-first century society, the growth of international conglomerates and news outlets, not to speak of the internet, complicates the model that posited the press primarily in its relationship to the state. As Pharr and Krauss note, over the past century, the "media . . . include a wide range of actors in a variety of relationships to institutions, so it is not surprising that collectively they adopt no single consistent stance in relation to state and society." My focus here is on two important actors in print journalism: national and regional newspapers. While acknowledging that the broader media "mosaic," and especially electronic media, is "discontinuous, skewed, and nonlinear," it is outside of the scope of this article to examine the news media in its entirety. ${ }^{11}$

\footnotetext{
${ }^{7}$ Laurie Anne Freeman, Closing the Shop: Information Cartels and Japan's Mass Media (Princeton: Princeton University Press, 2000$), 10$.

${ }^{8}$ Jürgen Habermas, The Structural Transformation of the Public Sphere: An Inquiry into a Category of Bourgeois Society (United States: The MIT Press, 1991), 182.

${ }^{9}$ On this value of impartiality, see Shibayama, Tetsuya, "Nihon kindai ni okeru genron rinen no keisei to shōgyo shinbun no 'fuhen futō," in Shibayama, Tetsuya, ed. Nihon no jaanarizumu to wa nani ka: jōhō kakumei ka de hōryū suru daiyon no kenryoku (Tokyo: Mineruba shobō, 2004), pp. 37-43, Freeman, Closing the Shop, 40-41, and Oi, Shinji, et al, "The Japanese Journalist in Transition: Continuity and Change," in The Global Journalist in the Twenty-First Century, David Hugh Weaver and Lars Villnat, eds. (New York: Routledge, 2012), pp. 60-61. For a discussion of the historical debates over impartiality from Meiji, see James L. Huffman, Creating a Public: People and the Press in Meiji Japan (Honolulu: University of Hawaii Press, 1997), p. 145.

${ }^{10}$ Susan Pharr and Ellis Krauss, eds, Media and Politics in Japan (Honolulu: University of Hawaii Press, 1996), pp. $20-21$.

${ }^{11}$ Pharr, "Media as Trickster in Japan," in Pharr and Krauss, 37-38.
} 


\section{Newspapers Telling their Own Stories}

An examination of newspaper shashi brings to light the overlapping social roles that newspapers occupy over time, whether by choice or by circumstances. The chapters in the histories of Chūgoku Shinbun, Asahi, and Yomiuri covering the decades from the 1930s through the 1950s reveal first the workings of the companies in a time of total war and thus under the control of the state, and subsequently the introduction of values of a free press and freedom of speech but under the direction of an occupying force. A comparison of the three company histories helps us see how differently the papers present the circumstances, negotiations, and choices of those days, as they aim at crafting a contemporary identity a half-century or more later. During the early postwar decades, Asahi and Yomiuri both had among the highest daily circulations in the world. Asahi is usually classified as a liberal newspaper, while Yomiuri is conservative. ${ }^{12}$

We can make certain assumptions about the shared goals and features of most shashi: creation of the company's image in extended narrative, inclusion of both successes and failures, and examination of social, political, cultural, and economic currents that shaped the business. All companies project cultural values and ideological stances when marketing products, but newspapers differ as products in their sustained narratives that communicate the outlook of the company and the freedom and restraints over the press and speech in a given age. The way a newspaper's shashi is written reveals the extent to which the company is willing and able to play the role of a fourth estate in times of openness or adversity.

Scholars are one important audience for shashi, as they employ the shashi along with other sources (such as archival materials) for learning about a company. As noted by Mr. Yano Masataka of the Library of Economics, Tokyo University, researchers using privately owned archives face issues of controlled access to sources. ${ }^{13} \mathrm{~A}$ researcher, if not granted access to primary documents, may have to rely heavily on the shashi. In the case of a newspaper company, the product (the company's publications) also constitutes a type of source material. The Chūgoku Shinbun archives include published newspaper texts and images that are publically available, but also feature private, internal documents. Similarly, a company history produced for the purpose of commemorating a significant anniversary (the hundredth year of the company's founding, for example) will usually contain a mix of both public and internal documents. Because such company histories are part of a company's "life cycle," as Yano points out, the process of selecting and editing such documents, images, and objects for a company history is inevitably shaped by the image the company wishes to project. Thus the researcher must use the company history with caution.

As historians have long recognized, the writer of any history employs narrative genres such as tragedy and melodrama. Shashi authors are no exception, as shown by Keidanren's (Japan Business Federation) decision to feature renowned playwright and novelist Inoue Hisashi as a speaker in a forum it sponsored on company histories. Inoue confessed to having nearly a hundred company histories in his personal library, and enthused about company histories that employ familiar literary genres such as the epic and picaresque in order to narrate a company's rise to success and to celebrate "heroes" (eiy $\bar{u})$ among its employees. Similarly, scholars specializing in advising companies on shashi concur that a successful shashi depends on sound narrative form that tells a good story (sutoriisei) and emphasizes important themes in the company's lifespan. ${ }^{14}$

\footnotetext{
12 This article is not a survey of newspaper shashi in Japan, and aims at analyzing a selected sample of newspapers.

${ }^{13}$ Yano Masataka, "Corporate Records [Kigyō Shiryō] and Archives, With a Focus on Company Histories," (paper presented at the Workshop of Shashi Interest Group, Joint Conference of AAS and ICAS, Honolulu, Hawaii, March 31, 2011).

${ }^{14}$ Inoue's comments are summarized in Nihon Keidanren taimuzu No. 2847 (15 February 2007)

http://www.keidanren.or.jp/japanese/journal/times/2007/0215/04.html. See also comments by Takeda Haruhito, a Tokyo University economic history professor who has published many scholarly works and authored shashi for many companies, and Kikkawa Takeo of Hitotsubashi University. Nihon Keidanren taimuzu No. 2941 (5 March, 2009), http://www.keidanren.or.jp/japanese/journal/times/2009/0305/05.html.
} 


\section{Chūgoku Shinbun as a Regional Paper}

Comparison of the narrative approaches used to represent several aspects of the tales told by Chügoku Shinbun and the two national papers, including the papers' role in wartime Japan, the aerial bombing and preparedness, and the censorship of the Allied Occupation of Japan after the end of World War II, is instructive. The analysis of the Chügoku Shinbun is based on the hundredth-anniversary history (the third history for the paper after the sixty-fifth and eightieth anniversaries), as well as a DVD/booklet set titled 1945: The Atomic Bomb and Hiroshima published on the $120^{\text {th }}$ anniversary. The company printed 3,500 copies of the hundredth-anniversary company history (hyakunenshi) for distribution to employees, other newspapers, libraries and schools in Hiroshima Prefecture, and other libraries, including the National Diet Library. ${ }^{15}$

In-depth coverage of the local news defines a regional newspaper. In its selection of an unusual page format for the shashi, with the historical narrative occupying the top three-quarters of the page, and quotes from sample articles about local news in a smaller typeface and single space in the bottom quarter, the Chügoku Shinbun steers the reader to the narrow, neighborhood focus of some sections of the paper. The two volumes also include black-and-white images of feature articles and parts of the newspapers, as well as black-and-white and color photographs of newspaper staff and facilities.

Before the a-bombing, during Japan's wars of the 1930s and 1940s, this regional newspaper's presence was felt in many communities because it had extensive circulation throughout the Chūgoku region. Although there were three local newspapers well into the 1930s, the Chügoku Shinbun alone survived and became an increasingly powerful media presence due to several factors. First, it conformed to the imperial government's demands on newspapers. That, along with aggressive management and a lack of vigorous competition, meant that the 1930 s and especially the 1940s Pacific War years were particularly stable for the Chügoku Shinbun. It thus became one of the dominant, most widely circulated sources of news and cultural reporting for hundreds of thousands of local readers.

Despite its emphasis on the local, the Hiroshima newspaper's company history details not only its role in the postwar social, cultural, and economic development of this medium-size city, but also narrates in considerable detail the company's involvement in national affairs, and especially Japan's modern wars. The shashi includes photographs documenting this involvement. One, for example, shows a notice in which the editors respectfully asked that readers tolerate the "temporary" reduction in number of pages due to the paper rationing and the frequent need to print special editions with urgent news of wartime events in Manchuria and China. ${ }^{16}$ Another photograph features company employees dressed in military uniform and waving the company flag on their way to a spiritual training camp (renseikai) at a Shinto shrine. ${ }^{17}$

The Hiroshima paper's shashi offers an account of wartime that differs in emphasis and detail from those of the national newspapers, which focus more on the impact of wartime mobilization on the company's business, management decisions, its product, and the newspaper industry as a whole. While the Chūgoku Shinbun shashi does discuss government controls over newspapers such as restrictions on length, paper rationing, consolidation, and censorship, the narrative foregrounds the integration of wartime into the daily life of Hiroshima. Consistent with the newspaper's own feature articles, the Chūgoku Shinbun shashi discusses the role of local women's groups in mobilization, the presence of the $2^{\text {nd }}$ General Army Headquarters and the $59^{\text {th }}$ Army in Hiroshima-in other words, topics that the newspaper reported on in feature articles. Even the company's own contributions to the war effort are

\footnotetext{
15 Email correspondence from Tashiro Akira, Chūgoku Shinbun journalist and editor, 28 November 2012.

${ }^{16}$ Chūgoku Shinbun hyakunenshi, 170.

${ }^{17}$ Chūgoku Shinbun hyakunenshi, 182.
} 
presented like feature stories, with names of individuals and close-up photographs. The history notes that the paper dispatched reporters to the front from the time of the "Manchurian Incident" (the Mukden Incident that was pretext for Japan's invasion of northern China) in 1931. The shashi reveals the paper's use of human-interest stories in war coverage by including the oval cameo photographs of individual embedded reporters, with captions providing their names and ages, from the daily paper. A formally posed photograph of the company's new film camera crew on its departure to join the Fifth Division's advance into Southeast Asia in 1940, flanked by the company president and other top managers, clearly shows the emphasis the paper placed on its staffs' contribution to the war effort. In contrast, the Asahi and Yomiuri shashi do not discuss the content of local features, even though their Tokyo, Osaka, and regional editions certainly did print articles on these topics.

This difference in shashi content is not simply a matter of national newspapers emphasizing national coverage. In the case of Hiroshima, the shashi's telling of the company's history is remarkably consistent with those local histories articulated by the Hiroshima city hall and the Peace Museum. In contrast to other cities in Japan, Hiroshima, along with many other local institutions, has fashioned a remarkably consistent narrative of the city's history and identity, one that tells a story of deep involvement in the empire's project of modernization and its wars, of the continuity from Hiroshima's development as a modern city to the bombing, and of a will to learn from that long and complex history. ${ }^{18}$

To a greater degree than other newspaper's identities, that of the Chügoku Shinbun resonated with the changing discourses of the history of Hiroshima. As the city with the unfortunate identity of being the first populated area to be bombed by a nuclear weapon in wartime, Hiroshima made it a mission to advocate for peace and the abolition of nuclear weapons. The dominant narrative presented in the Hiroshima Peace Memorial Museum came about partly in reaction to the harsh critique of its initial presentation mainly of artifacts and photographs of the bombing and aftermath, without much historical contextualization. ${ }^{19}$ In turn, that critique, marshaled internally and externally, extended to the city itself, which had morphed from a desolate landscape of ruins to an official "City of Peace" in four short years, in the complex context of defeat, occupation, and sovereignty in the Cold War.

By the time the Chügoku Shinbun hundredth-year history appeared in 1993, the Peace Memorial Museum had, along with many other peace museums in Japan, renovated the exhibit space to include extensive historical background on the involvement of the citizens of Hiroshima and the city itself in the Total War that the Japanese government pursued during the Asia-Pacific War and the final stages of Japan's empire. Planning for the fiftieth anniversary of the end of World War II had also given rise to a debate about meanings of the war in a broad public arena, manifest in myriad television programs, books, public forum, movies, journalistic writings, and the mayor's annual Peace Declaration. Exhibits and media in the renovated museum explained in considerable detail Hiroshima's status as home to military facilities and industry that contributed to war efforts. ${ }^{20}$ This historical contextualization was deemed important in refuting the discourse of Japan's victimization, which had developed in the first decades after the war but had come under severe scrutiny during the Vietnam War, and in promoting dialogue about responsibility and complicity. ${ }^{21}$ As the Hiroshima museum and the newspaper both address

\footnotetext{
${ }^{18}$ This is not to say that other narratives of Hiroshima's history and the atomic bombing have not been generated. Various activist movements and oppositional groups are among cohorts that articulate other visions of the meanings of Hiroshima.

${ }^{19}$ See for example Laura Hein and Akiko Takenaka, "Exhibiting World War II in Japan and the United States since 1995," Pacific Historical Review, 76.1 (February 2007): 61-94.

${ }^{20}$ The Hiroshima Peace Museum historical exhibits are outlined on the website:

http://www.pcf.city.hiroshima.jp/virtual/VirtualMuseum_e/visit_e/est_e/panel/A2/2105_1.htm.

${ }^{21}$ On the shift from discourses of Japan-as-victim to Japan-as-perpetrator to more complex understandings of Japanese history in the first half of the twentieth century, see James Orr, The Victim as Hero: Ideologies of Peace and National Identity in Postwar Japan (Honolulu: University of Hawai'i Press, 2001), Lisa Yoneyama, Hiroshima Traces: Time, Space, and the Dialectics of Memory (Berkeley: University of California Press, 1999), and Ran Zwigenberg, "'The Coming of a Second Sun': The 1956 Atoms for Peace Exhibit in Hiroshima and Japan's Embrace of Nuclear Power," The Asia-Pacific Journal, 10: 6 no.1 (2012) http://www.japanfocus.org/-Ran-Zwigenberg/3685, among others. In Hiroshima,
} 
international audiences, the shift in presentation about the bombing and Hiroshima over the seven decades since the end of the war also indicates an awareness of the radically different perspectives on twentieth-century history among audiences from China, Korea, and the United States, for example. ${ }^{22}$

Many aspects of the shashi align closely with the narrative told in the Peace Museum about the blurring of combatant and civilian in mobilization for Total War. Readers of the Hiroshima shashi will notice the frankness about the centrality of newspapers not only in the wars with China and the Allies in the 1930s and 1940s that lead to the bombing of Hiroshima, but in all of Japan's modern wars:

Newspapers are closely tied to war. This newspaper, in particular, evolved in step with Japan's modern wars. Shortly after the newspaper's founding, [we] encountered the First SinoJapanese War [1894-1895] . . and subsequently the Russo-Japanese War (1904-05), World War I, and the Siberian Intervention in 1919. The Showa period started with the Manchurian Incident of 1937 and continued with the Second Sino-Japanese War and the Pacific War. Given this context, it was imperative that the company have specialized war correspondents. A newspaper's ability to hire and train highly qualified war correspondents was key to the company's survival; this paper throughout its history thus made it a priority to foster war correspondents. ${ }^{23}$

In this way, the shashi aligns with the museum in its historicization of the atomic bombings, which creates a narrative that shows the atomic bombing to be part of a much longer process, familiar around the globe, in the development of the modern state and war.

Although the zenkokushi shashi articulated modern war as part of the nation's history, they did not do the hard work of tracing the entanglement of the local with the national and the global, as the Chügoku Shinbun did. The Asahi and Yomiuri's narratives about war and militarism return repeatedly to the centers of power. The concentration of power in Tokyo meant that government and military offices were located in close proximity to the newspaper headquarters. Thus the shashi describe Imperial Headquarters, edicts from the Cabinet's Information Office (naikaku jōhōkyoku), and prime ministers, rather than neighborhoods sending their sons off to war.

Unlike the Hiroshima Peace Museum, the Hiroshima newspaper does not exist as an organ of the "City of Peace" charged primarily with conveying a moral message about the evils of nuclear weapons. In narrating its own history in the postwar, this newspaper situates itself as part of the "fourth estate" guarding "against the unrestrained exercise of power by vested interests" in a democratic society. ${ }^{24}$ In this way, the Chūgoku Shinbun shashi aligns more closely with the Asahi. Both books also confront their own role during imperial history frankly. Yet each broaches the question of accountability (sensō sekinin) very differently. Asahi specifically addresses war responsibility, both by telling its history in great detail and constantly in relation to the state, and by articulating the ways the company felt obligated from the time of the Tokyo War Crime Trials to examine its own culpability.

former mayor Hiraoka Takashi, journalist Kanai Toshihiro, literary writers Kurihara Sadako, Tōge Sankichi, and Ōta Yōko are among those who took an important role in this long debate.

${ }^{22}$ The Chügoku Shinbun has dedicated considerable resources to its English webpage for non-Japanese readers called the Hiroshima Peace Media Center: http://www.hiroshimapeacemedia.jp/mediacenter/index.php. The newspaper staff is involved in on-going dialogue with the Peace Museum and other institutions in the city and region about peace education, hibakusha welfare, and antinuclearism.

${ }^{23}$ Chügoku Shinbun hyakunenshi, 156-157.

${ }^{24}$ Freeman, Closing the Shop, 3. 


\section{Doing Business in Wartime}

The Chügoku Shinbun shashi has in common with the two national papers a concern with the challenges of doing business in wartime. All three histories describe the ways they dealt with the mechanisms of increasingly strict state control and the measures they took to prepare for and to recover from the material destruction resulting from extensive aerial bombing. In the course of narrating these events and processes, moreover, the shashi authors had to come to grips with newspapers' social roles in wartime.

From the late 1930s, the Japanese government tightly controlled newspaper production through a wide variety of means: strict censorship, control over content, and rationing of paper and other materials. The government required that newspapers print articles, content, and notices that it provided. By late in the war, the Cabinet's demands meant that a full third of the daily paper was devoted to military news. The role of the press in shaping public opinion and setting agendas according to its own editorial policy was thus squashed by the wartime regime, because the Japanese state regarded newspapers as mouthpieces of the state. Consolidation also was an important tool of control. Restricting newspapers to one paper per prefecture meant that many smaller papers merged with other regional papers, while others were bought by one of the national newspapers.

The Chügoku Shinbun was the sole newspaper in the region to survive the process of forced consolidation (mochibun gōdo) of national and regional newspapers. Even it had to publish jointly with the Asahi and Yomiuri late in the war; all surviving regional newspapers were required to print the names of the national newspapers along with their own in the stylized nameplate on page one. Happily for the Hiroshima paper, consolidation resulted in increased circulation from 110,000 daily in 1942 to 200,000 at the end of the war in $1945 .{ }^{25}$ Not surprisingly, both the Yomiuri and Asahi shashi express their chagrin at the drastic loss in circulation resulting from this wartime measure.

With paper shortages as an excuse, the government reduced the length of all newspapers to two pages, once a day, from November 1944. For companies used to producing two editions of 6 to 14 pages in length daily, it was a daunting challenge to fit both news and advertisements (a key source of revenue, along with subscriptions) on a single sheet of paper, front and back. Yet the shashi approach these wartime challenges in very different ways.

Perhaps because of scale and their literal and figurative proximity to power, the national newspaper shashi are sensitive to this relationship with the government and their own roles, as already influential media outlets, in advancing wartime propaganda and total war mobilization. Interestingly, the conservative Yomiuri shashi notes a minor instance of resistance in its wartime editorials. It proudly highlights in a nearly half-page box (with dark borders) editorial writer Shimizu Ikutarō's despairing editorial, quite late in the war, in which he comments on the government's insistence that the way ahead is safe, so the people should advance confidently. The shashi speaks admiringly of the Yomiuri president, Shōriki Matsutarō, for not chastising Shimizu for his veiled criticism of the state. This is a surprising portrayal to readers who know Shōriki as a controversial company head, who was classified as a Class A war criminal during the Occupation but was depurged by GHQ during the Reverse Course, and who later returned to head the company, among many other prominent roles. ${ }^{26}$ But perhaps image change is precisely the point in the Yomiuri shashi. The Asahi shashi makes no such claims of valiant rebellion.

\footnotetext{
${ }^{25}$ Hyakunenshi, p. 237. Koike Seiichi states that the circulation rose to over 380,000 by 1944 in "Chügoku Shinbun, Chūgoku Shinbunsha no senzen to sengo" in Hibakushi Hiroshima no fukkô katei ni okeru shinbunjin to hôdô ni kansuru kenkyū chôsa, 2009, http://home.hiroshimau.ac.jp/hua/public/mitsubishi/mitsubishi01.pdf.

${ }^{26} \mathrm{He}$ continued his role as president of the Yomiuri, headed up Nippon Television, and served in the Diet. His role in promoting nuclear energy in Japan in collaboration with the CIA is described in Arima Tetsuo, Genpatsu, Shôriki, CIA, (Toko: Shinchōsha, 2008).
} 


\section{The Destruction of Facilities}

As the war started to affect the home front, the government's intrusive hand was not the only disruption of normal routine. All three companies lost their headquarters and main production facilities in aerial bombing raids that caused the deaths of a hundred thousand people or more. Even with conventional weapons, the number of casualties was larger in Tokyo, because of repeated air raids and a much larger total population. For the larger scale national newspapers, the extensive destruction caused by the aerial bombing in cities and towns throughout the country meant not only disruption of normal business operations, but also of their central mission of disseminating news to all corners of the country.

The Yomiuri shashi places heavy emphasis on its own sense of its purpose as a national newspaper by describing as "the nearly worst state of affairs" (saiaku ni chikai jitai) the 13 March 1945 Cabinet edict that dictated a ban on shipping national newspapers to the provinces as part of emergency measures for newspapers (Shinbun hijō jisei ni kansuru zantei sochi yōkō). ${ }^{27}$ According to the Yomiuri shashi, "once railroads and roads were destroyed [by bombing] and the national newspapers were no longer able to reach the provinces, all regions were starved for information. Moreover, this situation threatened to give rise to social unrest from the provinces due to pessimism about the outcome of the war." 28 This apparently altruistic sense of responsibility for the knowledge base in the provinces and social stability of the nation as a whole should be seen in the context of the fierce entrepreneurial spirit that prompted the national newspapers to expand aggressively into the provinces (from the mid-1920s) and to compete with local newspapers. The national newspapers were, furthermore, competing with each other for a larger share of the national market. In relation to the rationing of paper that started in 1938, for example, Asahi frankly acknowledges its competition with other national newspapers such as the Yomiuri and major Tokyo papers such as the Tokyo Mainichi Shinbun (precursor of the Mainichi). ${ }^{29}$

The Yomiuri shashi's claim that is was the sole conduit for information to the provinces should not be taken at face value. At the very least, local newspapers, the radio, and wire services were other sources. The shashi furthermore is advancing the Yomiuri as the keeper of public order in historical circumstances when such a role would be exclusively at the state's bidding and strictly in line with the state's policies. The shashi author makes this claim without a bit of irony, as if proud of the newspaper' disciplinary role in the name of the empire. ${ }^{30}$

\section{Business after the Bomb: A Tale of Recovery}

In comparison to the national newspapers, which describe the Tokyo conventional air raids and their aftermath in a summary way, the Chügoku Shinbun shashi renders extraordinary the story of what happened in the company after the bombing. It is this story of recovery, enabled by excellent preparation and individual heroism and the newspaper's sense of mission to serve the people of the community, that the Chūgoku Shinbun history emphasizes, rather than the bombing itself. Many dedicated employees are named, ones who, though injured themselves, worked hard to ensure the continued existence of the newspaper, even in the most dire of circumstances. More than one hundred of their colleagues at the paper, or one third of the staff, had perished.

\footnotetext{
${ }^{27}$ The national newspapers were allowed distribution in the immediate Tokyo, Osaka, and Fukuoka metropolitan areas only.

${ }^{28}$ Yomiuri Shinbun hyakunijūnenshi (Tokyo: Yomiuri Shibusha, 1994). 178.

${ }^{29}$ Asahi Shinbunsha, ed. Asahi Shinbun shashi: Taishō Shōwa senzen hen (Tokyo: Asahi Shimbunsha, 1995 ), $572-573$.

${ }^{30}$ In contrast, the Chūgoku Shinbun's 2012 DVD and booklet 1945: The Atomic Bomb and the Chūgoku Shinbun,while citing this same idea that the newspaper plays a central role in keeping public order, disassociates it from the imperial context and employs it in a heroic narrative to describe the positive role of the press.
} 
On August 6, 1945, the company headquarters of the Chügoku Shinbun was decimated by the atomic bomb blast. The company headquarters was a little over a 1,000 meters from the hypocenter. One employee who survived decided that he had to report the news, and so searched for the news service office, but it had been destroyed. He finally was able to send out word of the bombing from a military facility further out of town. Despite it all, this reporter went about his business. And, as employees of the largest publishing facility in the region and the press, the surviving reporters, editors, and copywriters decided to go to the home of President Yamamoto, located away from the central city.

Along with the determination and dedication of the staff, two other factors contributed to the relatively rapid resumption of printing of the newspaper. First, as the war and aerial bombing grew more severe throughout Japan, the paper developed an elaborate back-up plan, should the printing facilities suffer damage. Since virtually every major and medium-size city had been subject to aerial bombing attacks, publishers naturally anticipated widespread destruction. The Chügoku Shinbun's plan included a lengthy list of alternate printing facilities throughout the Chūgoku region, should the main facility in the city of Hiroshima be hit. First on the list of backups was the nearby port city of Kure, which, as it turned out, was one of the most extensively fire bombed cities that year because of Imperial Naval facilities and shipyards in the port city. After Kure sustained two hours of carpetbombing in July, the Chügoku Shinbun plant there ceased publication on 1 August.

Despite this level of destruction near and far, the newspaper managed to print special editions just days after the bombing, and resumed regular publication within several short months. The shashi describes the resumption of publication and the DVD 1945 shows a surprisingly ordinary (for wartime, that is) front page of the August 9 paper, with an advertisement for Jintan mints (a local product) — only three days after the bombing. That very first post-bomb paper was printed by the Mainichi newspaper in another city; it was wartime practice for newspapers to print for other companies in the event of emergency. Surviving employees continued to run the business out of the home of President Yamamoto, subsequently using a single printing press that survived in the village of Nukushina.

One of the heroes of the shashi's tale is company president Yamamoto Jitsuichi, who is credited with having the foresight to make multiple back-up plans for production facilities in the almost certain event of aerial attack of the city. It is President Yamamoto to whose home the surviving reporters and staff went after they found the newspaper's headquarters totally burnt out, and again when a typhoon hit hard very soon after the trauma of the bombing. It is his home that becomes headquarters for the duration, as the newspaper and the city work with determination to recover.

The shashi offers a vivid telling of the story of the survival of a "single large-scale rotary press printer" and prominently features a photograph of this printing press, instrumental as it was in the Chūgoku Shinbun's nearly immediate resumption of its role as Hiroshima's source of news and meaning. ${ }^{31}$ This image reminds us that the company had prepared well for the aerial bombing-even though it was conventional weapons that everyone anticipated--by evacuating the large piece of equipment out of the city proper.

The Chügoku Shinbun company history also features a photograph of a rotary press blackened and distorted by the heat from the atomic bombing of Hiroshima. Many histories of the Hiroshima and Nagasaki bombings have entirely disregarded the local press, assuming from images of the central city's destruction that there was no one left to write articles, no one left to read, no printers intact, no one to run the printers, in all of Hiroshima. The Chügoku Shinbun shashi proudly corrects this omission of its role in the recovery of Hiroshima.

\footnotetext{
${ }^{31}$ Chügoku Shinbun hyakunenshi, 184.
} 
Such disregard for regional publishing is also a result of centralization of Japanese publishing in Tokyo during the twentieth century-a trend that has continued to this day. ${ }^{32}$ This concentration of the publishing industry in Tokyo had the additional effect of solidifying the authority of writers, intellectuals, critics, and artists in Tokyo, and drawing attention away from regional cultural production. ${ }^{33}$ Just as national newspapers felt compelled to carry on with the business of making a newspaper and delivering the news even in horrific circumstances because it was their duty, so did the local paper. In fact, the Asahi and Yomiuri both had small branch offices in Hiroshima and Nagasaki, and lost employees there too. ${ }^{34}$

\section{Preparations for Disaster}

In contrast to the Chūgoku Shinbun's dramatic account of perseverance, dedication, and heroism surrounding this single printing press, the Asahi and Yomiuri shashi describe their preparations for bombing and recovery more as part of ordinary business cycles, rather than part of a heroic tale. These other company histories also demonstrate that the Chūgoku Shinbun level of preparedness was not exceptional, and, though none of the three shashi mention it, one surmises that the plan to evacuate equipment and supplies originated in the Cabinet, or at the very least in the organization of newspapers to which every newspaper was required to belong.

In anticipation of aerial bombing raids on large- and medium-sized cities, the government, from January 1944, initiated forced evacuations of various cohorts such as school children and mothers and infants. The zenkokushi blandly describe the evacuation of materials as measures aimed at protecting their own businesses. Both the Asahi and the Yomiuri evacuated equipment and supplies from central Tokyo in preparation for aerial attack. The Yomiuri shashi provides details of the considerable effort this required, though not in a dramatic fashion. The company removed over 20,000 publications from its Ginza (central Tokyo) headquarters archives/library (shiryōbu) to a storage facility in Saitama Prefecture, five high-speed printing machines (kōsoku rintenki), other printing equipment, typeface, and even carrier pigeons to Mito, Chiba, Urawa, and Shizuoka. Some of the evacuated equipment ended up being destroyed in bombing raids of those Kanto-region cities, but two printers in Urawa survived, and were the equipment moved back to Tokyo after the production facilities there were destroyed in the 25 May 1945 fire bombings. ${ }^{35}$

The Yomiuri shashi mentions multiple bombing raids over Tokyo, but describes in detail only the destructive 25 May 1945 raids that affected its operations. Concerning the destruction of its headquarters and main production facilities, the Yomiuri shashi places emphasis on the fact that the Yomiuri had survived relatively unscathed until the war was in its "final stages" and the defeat was near. By the time the headquarters burned in the massive May air raids, the shashi notes, the U.S. Navy had landed on Okinawa and the decisive battle closest to the homeland was well underway; Germany had surrendered, and Japanese military leaders were holding secret meetings. ${ }^{36}$ Consistent with the narrative approach of much of the Yomiuri shashi, the author juxtaposes carefully selected historical contexts with certain key incidents in the company's lifetime. In this way, the Yomiuri shashi

\footnotetext{
${ }^{32}$ Edward Mack, Manufacturing Modern Japanese Literature: Publishing, Prizes, and the Ascription of Literary Value (Durham, NC: Duke University Press, 2010).

${ }^{33}$ Richard Torrance has written insightfully about the notion of regional literatures and literary production in the Izumo and Osaka areas in: "Literacy and Literature in Osaka, 1890-1940," Journal of Japanese Studies, 31:1 (2005), 27-60.

${ }^{34}$ The Yomiuri Shinbun, a much larger firm than the Chūgoku Shinbun, lost 177 employees from the start of the war with China in 1937 through the end of the war in 1945. Of those, 45 were reporters, and 111 died while in military service. 21 died in bombing raids. Yomiuri Shinbun hyakunijūnenshi (Tokyo: Yomiuri Shnibusha, 1994). 174.

${ }^{35}$ Yomiuri hyakunijūnenshi, 179.

${ }^{36}$ Yomiuri hyakunijünenshi, 179.
} 
author admits to devastation only at the point when the outcome of the war is clear. It had fought the noble fight but once defeat was apparent, the narrative suggests, it was acceptable to collapse, like the rest of the country.

The Yomiuri's narrative strategy becomes clear when compared with the Asahi's approach to describing its involvement in the war. Even as it describes the complex and tense end stages of the war, the Asahi's shashi as a whole is relentlessly attentive to the monthly, daily, even hourly historical and political contexts in which it operated, as well as the newspaper's constant coverage of and engagement with the political and military events of its times. The most historically dense of the three, the Asahi shashi offers a detailed account of restrictions on the press, and of its own role in this process. Asahi vice president Ogata Taketora left his post to assume the head of the Cabinet Information Office (jōhōkyoku) of Prime Minister Koiso's cabinet in July 1944. ${ }^{37}$ The Asahi account of the destruction of its headquarters in central Tokyo is thus told as part of an ongoing narrative about the historical processes in which the company was deeply engaged. The Asahi shashi, furthermore, employed a much wider variety of sources for its company history, citing correspondence and other documents from the company archives and interviews with employees and evoking multiple points of view within the company. The four-volume history is painstaking in its level of detail, which makes it a broader history of decision-making, the press, and politics, rather than simply the story of a single business.

\section{A Monumental Event}

The three shashi all feature a separate section on their coverage of the Hiroshima and Nagasaki atomic bombings - something they notably do not do for the fire bombings, which, though featured in the newspapers, had become so unfortunately routine that the shashi do not single them out for in-depth coverage. The representation of the atomic bomb coverage reveals each company's perception of its role as a newspaper in society. The Chügoku Shinbun's approach is discussed above.

The Yomiuri shashi spins the Hiroshima account into a critique of the U.S. Occupation. The author highlights the apparent breakdown of official channels, noting the huge lag in official reports on the bombing ("a full thirty-one hours" after the bombing before a vaguely worded military report arrived). ${ }^{38}$ The earliest detailed news they heard was from an eyewitnesses who conveyed his account to the Osaka office by telephone, and finally from a Yomiuri reporter dispatched to Hiroshima from the Osaka office. That this reporter was allowed to publish such a detailed report of the damage to the city and interviews with Hiroshima residents about the experience of the flash and boom was exceptional, according the Yomiuri, because the government rarely allowed articles about damage due to aerial bombing. ${ }^{39}$

Newspaper reports of air raids over the hundreds of Japanese cities that had been bombed by the Allies normally excluded eyewitness accounts, numbers of casualties, types of injuries, and instead stated numbers of enemy bombers, time and date of the attacks, and formulaic expressions exhorting the Japanese people to rally and to continue to fight the enemy (a rhetorical device used in England and other countries, as well, about aerial bombing, the purpose of which was to break the resolve of the enemy). The Yomiuri shashi adopts a strident tone as it claims that the Japanese press owned the moral high ground in the days immediately after the bombing and before the surrender, in the reporting about Hiroshima and calling the bombing "uniquely cruel." In fact, the shashi author is borrowing language not from the Yomiuri's own pages but from famous editorials published by the Asahi on 8

${ }^{37}$ Asahi shashi, 570. Asahi pursues in detail Ogata's role in the Imperial Rule Organization, government, and journalism during wartime in Imanishi Mitsuo, Senryōki no Asahi Shinbun to sensō sekinin : Murayama Nagataka to Ogata Taketora (Tokyo: Asahi Shinbunsha, 2008).

${ }^{38}$ Yomiuri hyakunijūnenshi, 132-183

39 Ibid, 183 
August and after: "A cruel new weapon that disregards morality . . The enemy made exaggerated claims about this new weapon." ${ }^{40}$ However we may judge the use of the atomic bomb in hindsight, the contemporary charges of immorality in the pages of the Asahi were not signs of freedom of the press, or a step toward editorial autonomy. ${ }^{41}$ Furthermore, it is one thing for a newspaper to be allowed to make a claim of the enemy's cruelty during wartime, and quite another for a history written half a century later to make that same accusation, while at the same time trotting out the shopworn accusation that the Occupation's censorship was more egregious. The Yomiuri shashi author comments, "The U.S. Military used the Press Code as a means of hiding the horrors of Hiroshima [in katakana], and [we] had to wait until the Peace Treaty seven years later for the photographs of the [Hiroshima and Nagasaki] corpses to be exposed to the world." ${ }^{2}$ The Yomiuri author thus singles out the atomic bombings as uniquely immoral, without mention of myriad other instances of horrific brutality and slaughter on Japan's part, and on many sides, during the wars of the 1930s and 1940s.

Concerning its reporting of the atomic bombings in August, the Asahi offers a detailed examination of its own coverage of the story. The Asahi shashi describes its own editorials accusing the U.S. of extraordinary cruelty, but it also points out that continuing censorship meant that the paper was not allowed to use the term "atomic bomb" even though reporters were aware that Truman and Churchill had called it that, and the Cabinet had also been briefed on what type of bomb it was. The Asahi account describes a remarkable negotiation about what the newspapers should call the bomb (a new-type bomb/shingata bakudan or an atomic bomb/genshi bakudan) between reporters from various newspapers and the Cabinet Information [Intelligence] Office, even though everyone in the room knew perfectly well that the Hiroshima bomb was no ordinary bomb. ${ }^{43}$ That the newspapers were still under the thumb of the government censors is clear from the Asahi editorials that describe the "new bomb" as immoral, because they follow this claim with the exhortation to readers to firm their resolve to resist the enemy and carry on the fight. The Asahi shashi notes that, even though the press did not name the bomb and explained its destructive power in only the vaguest of terms, "it was inconceivable that the people would not spread the word of the bomb's power and destructiveness, and the news spread quickly around the country."44 This claim raises interesting questions about what the people knew despite the presses' silence throughout the war.

In contrast to the Yomiuri shashi's vague claim of freedom of the press after August 6, Asahi shashi emphasizes that the Cabinet continued to control the press even at this very late stage of the war. In an account of the 12 August 1945 edition of the paper, the Asahi shashi quotes from an article written by three Asahi reporters who were dispatched to Hiroshima. On the one hand, they acknowledge the power of the single bomb. Yet the reporters also state "we will not give in to this new weapon." They furthermore attribute the vastness of destruction to Hiroshima and Nagasaki residents" "lack of experience" (funare) with the new type of weapon. From now on, they warn, "be careful even if you see only one bomber" and keep in mind the efficacy of bomb shelters and Mercurochrome. The Asahi shashi comments, "without a doubt, the three reporters must have come away from the city with a very different impression of Hiroshima than what their report suggests, but censorship was very strict" at that time. $^{45}$

${ }^{40}$ Asahi Shashi, 641-642

${ }^{41}$ Asahi shashi offers a detailed account of government control over the Hiroshima news on August 6-8, 1945, 642-643.

42 Yomiuri hyakunijünenshi, 183.

${ }^{43}$ Other sources describe a meeting of the major newspaper editors and Domei wire service with the Cabinet Information Office around this time as a one-way dictation of what to write. See Monica Braw, The Atomic Bomb Suppressed (Armonk, NY: 1991), 11, quoting Fletcher Knebel and Charles W. Bailey, No High Ground (New York: Harper, 1960), 147. According to Braw, the Government of Japan "accused the United States of cruelty and inhumanity for using the atomic bomb" in an "official protest" to the U.S. government on August 12, just days before the surrender. The criticisms of the U.S. were consistent with those issued domestically by the military since August 7. Sections of protest were published in the Asahi.

${ }^{44}$ Asahi shashi, 643

45 Asahi shashi, 642. Also cited in a slightly different translation in Braw, 14. Braw's claim that "several reports endorsed preparations for living underground" is surely anachronistic, given that the identity of the bomb was not confirmed yet and the effects of radiation at that scale were not 


\section{The Occupation Years}

After years of increasingly harsh control of newspapers' contents and materials by the Imperial government, the Allied Occupation severed Japanese government control of newspapers and implemented its own Press Code in 1945. These measures marked a significant shift for Japanese newspapers. The Chūgoku Shinbun's account of the effect of Allied Censorship is remarkably matter of fact, emphasizing the Code's goal of free press and freedom of speech: the GHQ's document states that it "is designed to educate the press of the Japanese in the responsibilities and meaning of free press." 46

As a means of emphasizing the myriad controls that the Imperial government had placed on the press, the Hiroshima shashi enumerates no fewer than ten major pre-1945 restrictions on the press and society. ${ }^{47}$ Although the shashi starts the list with the time marker "wartime," in fact the implementation of many of these oppressive laws dates back to the early twentieth century.

Monica Braw emphasizes the censorship by the SCAP of national newspapers but omits the local press almost entirely in her book The Atomic Bomb Suppressed: American Censorship in Occupied Japan. ${ }^{48}$ The Chūgoku Shinbun's company history allows readers a very limited glimpse into the workings of Allied censorship in Hiroshima. In contrast to widespread criticism of the Press Code and GHQ censorship as harsh-some claim even worse than Imperial censorship because it was kept a well-known secret - the Hiroshima shashi remembers the Press Code as having been relatively "lenient" or low-key (öraka). ${ }^{49}$ During the Occupation, GHQ would maintain many features of the imperial system of control, such as restriction on number of pages and reduced paper supply. The Hiroshima paper's claim of low-key GHQ control contradicts evidence of strict attention to some Hiroshima publications, as in the case of writer Kurihara Sadako's famous poetry collection Black Eggs, which can be seen in the Prange Collection at University of Maryland. It also conceals the vigorous supplying of content by the Occupation authorities that is evident in issues of the newspaper of that period, such as press releases from UPI and other foreign press services and from GHQ itself. Examination of the Prange Collection confirms, however, that the Allied censors left large parts of printed material untouched, but it is highly unlikely that it would not have monitored the Hiroshima newspaper closely. For that reason, the Chūgoku Shinbun company's relationship with the Occupation authorities merits further investigation.

\section{Conclusion}

Who reads shashi? Newspaper companies, constantly aware of their newspapers' readers' preferences and needs, seem equally aware that their shashi will not sit on the shelves gathering dust. Indeed, the biases, narrative approaches, and sources of three shashi discussed here suggest that the companies anticipate readerships for their shashi very similar to those of their newspapers. In short, the Asahi tends to attract an intellectual, progressive audience, whereas the Yomiuri has a broader appeal with more conservative or apolitical readers. The Chügoku

known. The Asahi shashi quotes from news reports soon after the bombing encourage use of bomb shelters to seek temporary protection from air raids, a regular part of war time preparations of non-combatants in Japan.

46 "Press Code," http://wwwdev.lib.umd.edu/prange/images/japanese_presscode.pdf.

${ }^{47}$ Hyakunenshi, 207.

${ }^{48}$ Braw. Atomic Bomb, 32-44.

${ }^{49}$ Hyakunenshi, 207. 
Shinbun, regarded as liberal, engages with regional audiences, anticipating and fostering a readership exposed from a young age to discourses of anti-nuclearism and Hiroshima's advocacy for peace.

I close by noting one of many instances when a newspaper company uses the shashi as basis for a publication or broadcast intended for a public audience. Newspaper companies in contemporary Japan, it is worth noting, also publish books and, in cooperation with affiliated television stations and websites, as well as NHK, offer content to their customers in a variety of forms.

In commemoration of its hundred and twentieth anniversary, the Chūgoku Shinbun company produced a television series/DVD and booklet called 1945: Genbaku to Chügoku Shinbun (1945: The Atomic Bomb and Chugoku Shinbun, 2012). ${ }^{50}$ The television series was shown to local audiences in the Hiroshima area in spring, 2012, just a year after the 3-11 tsunami and nuclear disaster. While this handsomely produced set tells the history of the bombing, the timing of its release and the content resonate profoundly with the Fukushima disaster through its message of the will of the newspaper and its workers to survive and to fulfill its function despite the extent of damage and death.

The series adheres closely to the shashi's heroic story of the company employees rallying to rescue the paper, and includes even more detail about the evacuated printing press, with a visit to the farm in Nukushina where the newspaper temporarily set up shop and started to print again. 1945 tells the story of a newspaper that was not only dedicated and hopeful, but one that, after a disaster of that magnitude, was an essential part of its community and the city of Hiroshima. As part of telling this epic story, the author does not go into much detail about the complex context of imperial Japan, a potentially problematic move. Yet, clearly the impetus to do so in 2012 is not to reinstate the victimization narrative, but instead to recognize the commonalities of events of massive destruction and their aftermath. So soon after the tsunami and nuclear disaster (characterized also by loss of faith in state), the program aims to illustrate an instance from the past of recovery from disaster and to offer a message of encouragement to the living. In the series, publishing on its own power (jiriki insatsu) becomes a metaphor for autonomy and ability to survive, and to step away from the apparatuses of state control.

On the other hand, through interviews with former employees who experienced the bombing, the DVD series recognizes the individual effort of employees who contribute to the revival of the paper, highlighting themes of agency, continuity, and basic human decency. 1945 also offers a franker examination of the effects of radiation on the hibakusha, again with Fukushima in mind. The $120^{\text {th }}$-anniversary series also places emphasis on themes that the shashi does not, foregrounding the newspaper's early role in advocating for the hibakusha to the central government, by showing an editorial in the first issue after the bombing that advocates for care and support for the hibakusha from the government in Tokyo (chīō ni apiiru suru). The long neglect of the medical, psychological, and social needs of the hibakusha, many of whom suffer from the long-term effects of radiation poisoning, has been an issue that the newspaper, along with many hibakusha groups, highlighted for many decades.

The release of 1945: Atomic Bomb and Chügoku Shinbun is clearly a response not only to the contemporary issues surrounding the 3-11 Fukushima nuclear disaster, but also to the precarious position of newspapers in the twenty-first century. The first issue consumes the news media in Japan, which look to history for explanations of the historical processes that contributed to the disaster but also seek models for survival of and recovery from any disasters. Some outsiders wonder how Japan and especially Hiroshima could have accepted nuclear power plants after the bombing, but research has revealed the extent of the marketing of nuclear power and social engineering by both Japanese government and industry and its Cold War ally the U.S., to the extent that the

50 1945: Genbaku to Chūgoku Shinbun. (Hiroshima: Chūgoku Shinbun, 2012). DVD and Booklet. The seven part series on the DVD was televised in 2012 on the CATV channel (affiliated with the newspaper) to a regional audience. The text and photographs in the booklet are also available on the internet: http://www.chugoku-np.co.jp/prf/120 1945/index.html. 
voices of those who did oppose the new technology were drowned out. ${ }^{51}$ 1945: Atomic Bomb and Chügoku Shinbun does not explicitly compare Hiroshima and Fukushima, but instead reviews the former as a means of informing readers who seek to understand the continuity and disjunctures. In the best fashion of newspaper feature writing, 1945 includes interviews with hibakusha, many in their 80s, who possess the authority of experience to communicate the fact of a nuclear bombing, the hope of recovery, and to render those experiences human. The growing awareness that a time is coming when no hibakusha will be present to witness in person adds a special urgency to the inclusion of the many interviews in the 1945: Atomic Bomb and Chügoku Shinbun film. The 1945 booklet acknowledges its goal in provoking these comparisons and the risks implicit:

In an age of increasingly diversified media, many people question the need for newspapers and point out their limitations. Since the tsunami and nuclear disaster of 11 March 2011, we again find ourselves confronted with the issue of how communities cope with unprecedented disaster, and with the potential for "peaceful uses" of the nuclear. We hope that this booklet will constitute an encounter with Hiroshima and a record that will connect those of us who live in the post-3-11 world with the people who will create the future. ${ }^{52}$

The chagrin of some hibakusha in Hiroshima and Nagasaki over their own past support of nuclear energy plants, even a short decade after the atomic bombing, reveals the complexity of the issue in Hiroshima. 1945 is consonant with the Chügoku Shinbun's efforts as a newspaper to explore the vexing questions about Japan's nuclear present, the challenges of the hibakusha (in the sense of all people exposed to unnatural levels of radiation), and the city's identity as it moves into the future. For example, in the series "Fukushima and Hiroshima," the Chügoku Shinbun newspaper brings to light the outreach efforts by Hiroshima hibakusha groups, scientists, and physicians to Fukushima area residents who, in their "unending battle with radiation," are discouraged by the contradictory advice offered by the government and TEPCO about radiation exposure levels in their bodies, homes, and communities. ${ }^{53}$ The newspaper describes initiatives by experts from Hiroshima, such as the Emergency Radiation Exposure Task Force formed by Hiroshima University and dispatched to Fukushima the day after the tsunami for the purpose of measuring levels of radiation, ascertaining the need for decontamination, and offering medical guidance and expertise. Dr. Kamiya Kenji of Hiroshima University asserted "It is the mission of Hiroshima to stand by Fukushima." The newspaper series also features hibakusha volunteers such as Okamoto Masako, who travelled to Fukushima to participate in decontamination efforts and notes that Hiroshima area election board officials went to assist in polling places in the Fukushima area.

At a time when the viability of newspapers is increasingly precarious, the $120^{\text {th }}$ anniversary publication and DVD show the newspaper as an institution that not only survived the bombing but that exemplified preparedness and determination to serve the community even in the worst of times. The Chügoku Shinbun chose to make public a part of the shashi (necessarily a format of limited circulation): the compelling story of the evacuated printing press and heroic newspaper employees.

\footnotetext{
${ }^{51}$ See Ran Zweiberg, "The Coming of a Second Sun," Daniel Aldrich's various publications including Site Fights: Divisive Facilities and Civil Society in Japan (Ithaca: Cornell University Press, 2010), among others.

52 1945: Genbaku, 3.

${ }^{53}$ See, for example, Seiji Shitakubo and Yo Kono, Staff Writers "Fukushima and Hiroshima: Collected Expertise and Wholehearted Support," http://www.hiroshimapeacemedia.jp/mediacenter/article.php?story=20120104161029816 en
} 


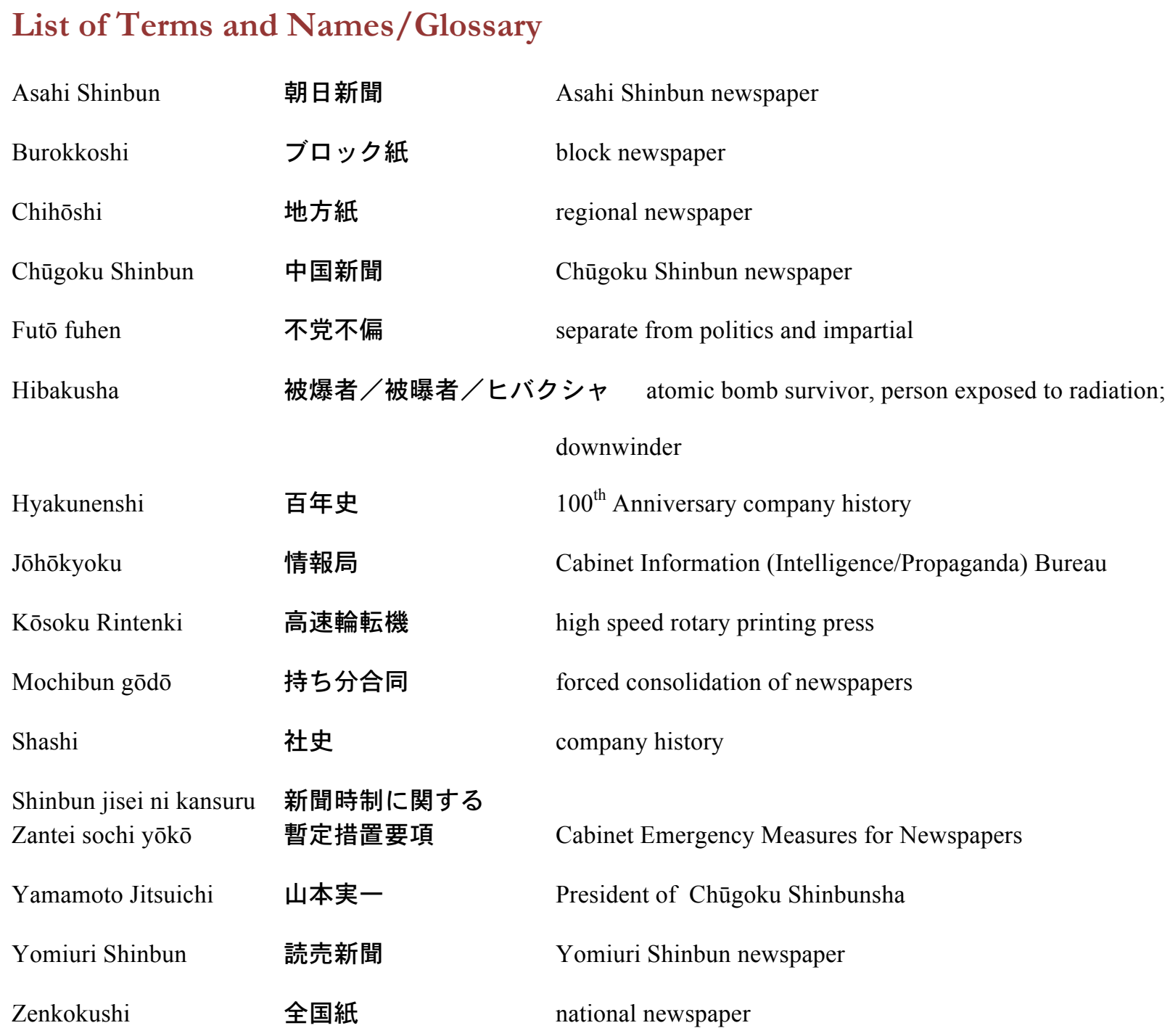




\section{(cc) $\mathrm{EY}$}

New articles in this journal are licensed under a Creative Commons Attribution 3.0 United States License.

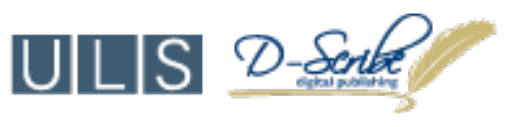

This journal is published by the University Library System, University of Pittsburgh as part of its D-Scribe Digital Publishing Program and is cosponsored by the University of Pittsburgh Press. 